\title{
Prispevek k proučevanju besedilnih spretnosti mladih v Sloveniji
}

Jasmina Mirčeva, Mirna Macur

\section{Uvod}

Izobraženost, usposobljenost in raven spretnosti prebivalstva imajo v t. i. »družbi znanja« za doseganje čim večje družbene blaginje, gospodarskega in osebnega razvoja pomembnejšo vlogo kot kdaj koli prej. Uveljavljeni teoretik Druker (1995) je opisal družbo znanja kot dinamično in razvojno usmerjeno, zanjo pa naj bi bilo značilno nenehno spreminjanje družbenih položajev in vlog ljudi. Avtor je ponazoril dinamiko v družbi s centripetalnimi in centrifugalnimi socialnimi silnicami, ki posameznike potiskajo proti višjim položajem in statusom ali na rob družbe. Ljudje si, zato da bi obstali v tej družbi, se lahko čim bolj približali središčnim tokom dogodkov ter dosegli čim večjo prosperiteto in kakovost bivanja, prizadevajo pridobiti in ohraniti ustrezno znanje, spretnosti in kompetence. Znanje in pridobivanje spretnosti sta dostopna večini prebivalstva, hkrati pa je v družbi neuspešnih vse več ljudi, ki imajo le nizke spretnosti.

Ta ugotovitev je še posebno relevantna za mlade, ki naj bi bili nosilci novosti, sprememb in razvoja v družbi. Po drugi strani nekateri kazalniki, analize in študije kažejo, da postaja populacija mladih precej ranljiva in deprivilegirana ter da je polarizacija med mladimi zelo izrazita. Še posebno so izključeni in marginalizirani mladi z nizkimi besedilnimi spretnostmi (Skills Matter, 2016; Literacy in the Information Age, 200o). Strategija Evropa 2020: Strategija za pametno, trajnostno in vključujočo rast (2010) opo- 
zarja, da ima skoraj četrtina mladih prebivalcev težave s spretnostmi. Več kot polovica dosega le spretnosti, ki ne zadoščajo potrebam na trgu dela. To velja tudi za Slovenijo, saj je po podatkih Eurostata brezposelnih skoraj $25 \%$ mladih, starih od 15 do 25 let. Problem mladih z nizkimi spretnostmi je eden temeljnih izzivov pedagoške in andragoške stroke tudi v Sloveniji (Eurostat 1990-2020).

Namen prispevka je, da se na podlagi podatkov raziskave PIAAC (Program za mednarodno ocenjevanje kompetenc odraslih 2012-2016) predstavijo besedilne spretnosti populacije od 16. do 24. leta starosti ter pojasnijo dejavniki, ki na to stanje in trende vplivajo pozitivno ali negativno. Skupina mladih ni homogena. Zaradi vpliva različnih dejavnikov (sociodemografskih, ekonomskih, družinskih, kulturnih itn.) je raven spretnosti mladih v Sloveniji diverzificirana. Predstavljen bo model, ki bo pokazal, kateri dejavniki najbolj vplivajo na raven spretnosti mladih oziroma kakšni so njihovi učinki na raven spretnosti mladih v Sloveniji.

Dejstvo je, da se polarizacija $v$ družbi reproducira $z$ mehanizmi izobraževanja že v mladosti. Pisni dosežki mladih so zelo različni. Ta polarizacija posameznikov v obdobju mladosti ni značilna le za slovensko družbo, temveč tudi za druge evropske in neevropske države. Presenetljiva pa je ugotovitev, da se kljub številnim državnim ukrepom razlike med skupinami ne zmanjšujejo, temveč se povečujejo. Polarizacija ima dolgoročno negativne implikacije, kot so visoka brezposelnost, mladi pogosto opravljajo slabo plačano prekarno delo, opažamo beg možganov in pojave, kot so apatičnost, psihološki problemi, kriminaliteta itn. Krajnc (2011) poudarja, da je naloga vseh vlad zagotoviti odprt dostop do znanja in spretnosti za vse.

Pri prikazovanju spretnosti smo uporabili strokovno izrazje, ki je bila uporabljeno pri raziskavi PIAAC. Spretnosti v tej zvezi izražajo merljivi del kompetenc. Kompetenca se opredeli kot sposobnost opravljanja nalog in vlog, ki so potrebne za doseganje pričakovanih standardov. Socioekonomski in kulturni kontekst naj bi bil tisti, ki določa pomembnost posameznih kompetenc (Muršak in Radovan, 2015). V raziskavi PIAAC so bile merjene besedilne, matematične in spretnosti reševanja problemov v tehnološko bogatih okoljih ${ }^{1}$. V tem prispevku smo se osredinili predvsem na prikaz besedilnih spretnosti. Razlog za to je, da so besedilne spretnosti, po navedbah

1 Po raziskavi Spretnosti odraslih: Vodnik za bralca (2013) so:

- besedilne spretnosti - sposobnost razumevanja in uporabe besedilnih informa-

cij v različnih kontekstih

- matematične spretnosti so sposobnost razumevanja, interpretacije in uporabe matematičnih informacij in zamisli; 
relevantnih virov OECD, najbolj vpete v življenje in delo odraslih, hkrati pa je raziskava PIAAC pokazala visoko korelacijo med dosežki v besedilnih, matematičnih in spretnostih reševanja problemov $\mathrm{v}$ tehnološko bogatih okoljih.

\section{Opredelitev kategorije mladih in njihove spretnosti}

Pojem »mladi« in obdobje »mladosti« se v literaturi ne obravnavata enopomensko. Zakonski dokumenti in uradna statistika ju opredelijo s starostnim intervalom. Uradna statistika se sklicuje na veljavno zakonodajo (Zakon o javnem interesu v mladinskem sektorju) in določa interval trajanja mladosti med 15. in 29. letom.

V strokovni literaturi najdemo predvsem kvalitativne kriterije opredeljevanja populacije mladih. Mužica (2012) je ta pojmovanja združila: mladost je opredelila kot obdobje med otroštvom in odraslostjo - čas, ko posameznik prevzame odgovornost do sebe, sočloveka in družbe (povzeto po Mirčevi in Možini, 2017).

Pri kvantitativnem merjenju spretnosti populacije mladih v tem prispevku smo izhajali iz opredelitve raziskave PIAAC (Skills Matter, 2016), ki se osredinja predvsem na interval med 16. in 24. letom starosti. Za interpretativne namene je bilo ponekod $\mathrm{v}$ analizo zajeto tudi obdobje med 24. in 29. letom. V populaciji mladostnikov je bila še posebno izpostavljena najnižja starostna kategorija med 16. in 19. letom starosti, ki ima svoje specifike.

Položaj skupine mladih se je sčasoma zelo spreminjal. Ule in Zidar (2011), ki sta spremljali razvojna gibanja, sta opozorili na nasprotujoče si obravnave mladih svetu in Sloveniji. Po vojni so bili mladi privilegirana družbena skupina - razvojni potencial družbe, nosilci družbenih gibanj, pobud, njihove zamisli so se prenašale na druge družbene skupine in generacije. V nasprotju s tem so v obdobju prehoda postali šibek člen v družbi. Pojma mladi in mladost se danes povezujeta $\mathrm{z}$ ranljivostjo. Ta skupina je družbeno, politično in ekonomsko manj pregledna. Avtorici menita, da se je avtonomija mladih v Evropi in Sloveniji precej zmanjšala, ko so se zaradi omejevanja socialne države stroški socialne reprodukcije mladih $\mathrm{z}$ države prenesli na družino. Tem spremembam je sledil tudi prehod diskurza o izobraževanju in pridobivanju spretnosti iz enakih možnosti v doseganje individualnih koristi. Posameznik je v zvezi s tem odgovoren za uresni-

- spretnosti reševanja problemov v tehnološko bogatih okoljih so zmožnosti, da se najdejo, izberejo, ovrednotijo in uporabijo informacije $\mathrm{z}$ uporabo novih informacijskih tehnologij za reševanje problemov in uresničevanje kompleksnih nalog. 
čevanje izobraževalnih ciljev (Ule, 2018). Takšna zasnova izobraževanja in učenja izključuje posameznike, ki ne morejo slediti pritisku individualizacije. Tako prihaja do favoriziranja nekaterih skupin, ki imajo priložnosti, motive in podporo za uresničevanje izobraževalnih in učnih ciljev, ter izključevanje drugih, ki so glede tega prikrajšane.

Berzin (2010) poudarja, da se obdobje mladosti podaljšuje. To omogoča tistim, ki imajo dovolj podpore, da izrabijo različne okoliščine za razvoj znanja in spretnosti, da uresničijo svoje cilje in ambicije, tisti, ki takih razvojnih priložnosti nimajo, pa se rekrutirajo v kategorijo ranljivih.

$\mathrm{V}$ nadaljevanju predstavljamo, kakšne so spretnosti mladih in odraslih v Sloveniji, in nato, kakšni so dosežki v primerjavi z njihovimi vrstniki v Evropski uniji in OECD.

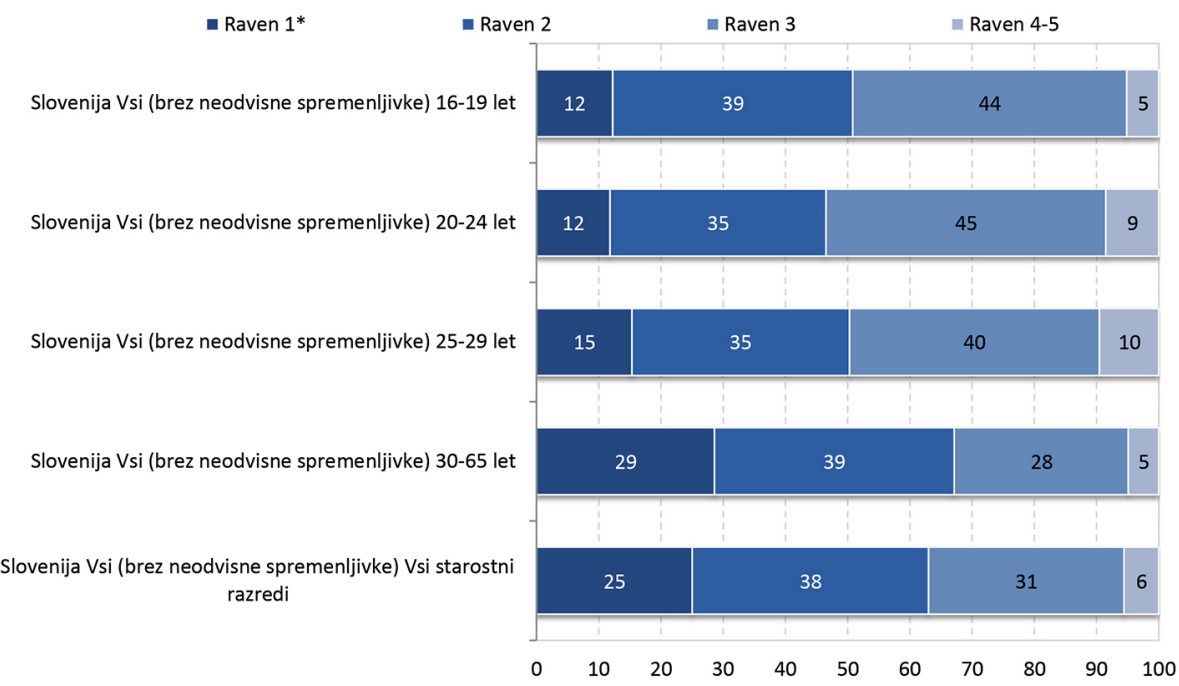

Slika s: Dosežki v spretnostih glede na starost, podatki za Slovenijo, raziskava PIAAC (2012-2015), besedilne spretnosti

Vir: OECD, 2016.

Podatki raziskave PIAAC kažejo, da spretnosti odrasle populacije niso enakomerno razporejene in da so spretnosti mlajše generacije nekoliko višje od tistih, ki jih dosegajo druge starostne skupine do 64. leta. Dobra desetina mladih dosega le prvo ali manj kot prvo raven spretnosti, to pomeni, da obvlada le osnovno besedišče. Nekoliko višji je delež najnižje uvrščenih v zgornji kategoriji mladih, med 25. in 29. letom starosti. Pri treh starostno razdeljenih skupinah mladih prevladujejo tisti, ki dosegajo tretjo raven be- 
sedilnih spretnosti - zaznavajo zgoščena in daljša besedila, ki jih razumejo, interpretirajo in ovrednotijo, pravilno sklepajo in izluščijo pomen prebranega. Vsaj tretja raven je po ocenah OECD tista, ki je potrebna za normalno delovanje v sodobni družbi, ki temelji na znanju. Relativno malo mladih iz vseh treh kategorij dosega četrto ali peto raven spretnosti (ta delež je višji v starostni skupini od 25. do 29. leta).

Kljub razmeroma dobrim dosežkom mladih $\mathrm{v}$ primerjavi z drugimi starostnimi kategorijami je zaskrbljujoč podatek, da manj kot polovica teh ne dosega želene tretje ravni.

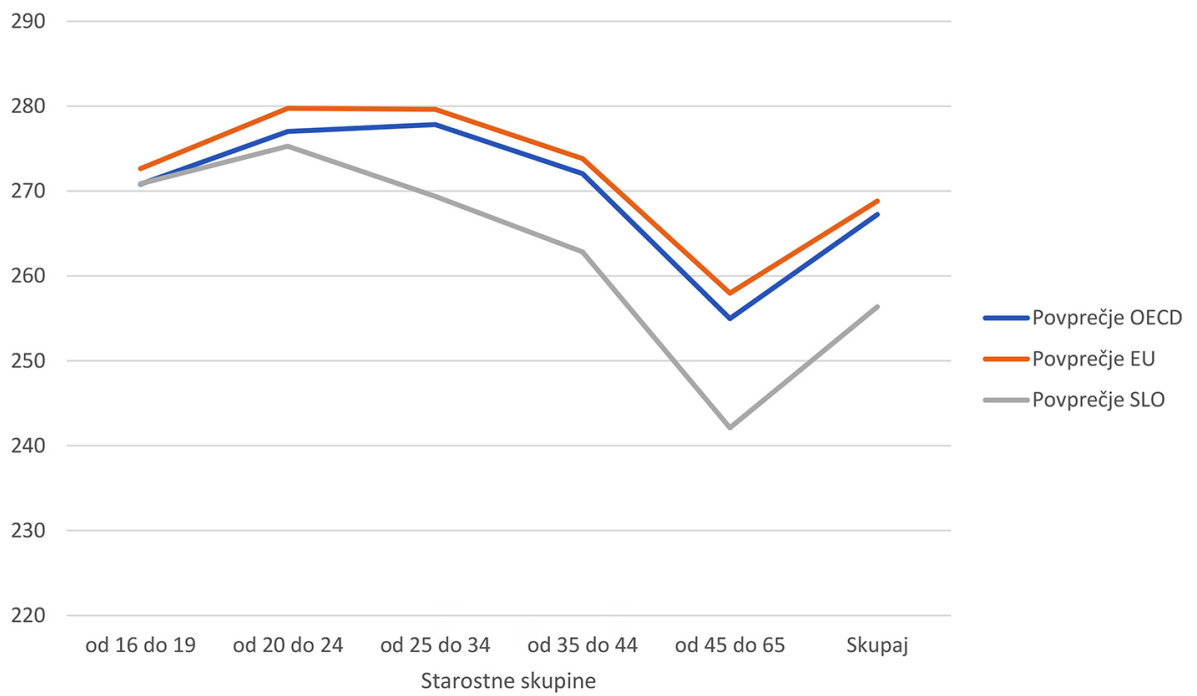

Slika 6: Besedilne spretnosti prebivalcev OECD, Evropske unije, Slovenije po starosti, rezultati raziskave PIAAC (2012-2016)

Vir: OECD, 2016

Besedilne spretnosti vseh starostnih skupin v Sloveniji so nižje od povprečja OECD in Evropske unije. Te razlike so manjše v populaciji od 16. do 24. leta starosti.

Besedilne spretnosti Slovencev so podpovprečne v primerjavi z besedilnimi spretnostmi odraslih v drugih evropskih in neevropskih državah, ki so sodelovale v prvem in drugem krogu raziskave PIAAC. Slovenija je povsem na koncu, slabša od nje sta le Italija in Čile (Skills Matter, 2016). 
Ta izid je nekoliko presenetljiv, saj izkazuje šolajoča se mladina po podatkih PISA in drugih raziskavah nadpovprečne rezultate in na splošni ravni ima Slovenija razmeroma razvejen sistem izobraževanja. Vendar je, kot kaže, sistem izobraževanja odraslih manj podprt in funkcionalen, zato so učinki temu primerno nižji.

\section{Metode}

\section{Vzorec}

Ambicija našega prispevka je odkriti, koliko mladih v Sloveniji ima težave $\mathrm{v}$ besedilnih spretnostih in njihove značilnosti. $\mathrm{V}$ ta namen potrebujemo reprezentativno bazo podatkov; uporabili smo del mednarodne raziskave PIAAC - Programa za mednarodno ocenjevanje kompetenc odraslih (OECD), ki ima zelo natančno določena metodološka pravila vzorčenja za pridobitev reprezentativnega vzorca v posamezni državi. Raziskavo so v sodelujočih državah izvajali v več krogih; Slovenija se je pridružila drugemu krogu (2012-2016). Ciljna populacija je bila določena skladno s standardi raziskave PIAAC in je zajemala odrasle od 16. do 65. leta starosti, ki so med zbiranjem podatkov prebivali v Sloveniji. Osebe so bile zajete ne glede na državljanstvo, narodnost ali jezik. Izključene so bile osebe, ki so prebivale $\mathrm{v}$ institucionalnih skupinskih gospodinjstvih, kot so zapori, bolnišnice in domovi za starejše. Izbiro vzorca je izpeljal Statistični urad iz Centralnega registra prebivalstva 1. 3. $2014 \mathrm{z}$ dvostopenjskim sistematičnim vzorčenjem in izdelal vzorčni načrt, v katerega je bilo zajetih 9000 oseb (Berzelak idr., 2016). Realizirani vzorec $(n=5156)$ je reprezentativen za osebe, stare od 16 do 65 let. Ta datoteka je skladno z metodološkimi pravili PIAAC utežena na raven populacije, zato vsi izračuni podatkovne baze PIAAC prikazujejo populacijske vrednosti za to starostno skupino.

$\mathrm{V}$ prispevku se osredinjamo na populacijo mladih: kategorija mladih je opredeljena s starostjo od 16. do 24. leta. V slovenskem vzorcu je bilo takšnih 836, od teh je bilo 371 starih od 16 do 19 let ter 465 od 20 do 24 let. Med mladimi, starimi od 16 do 24 let, je bilo 51,7 \% moških in 48,3 \% žensk. V Sloveniji je bilo ob zbiranju podatkov 193.464 mladih, starih od 16 do 24 let, zato vse predstavljene frekvenčne porazdelitve v prispevku prikazujejo populacijske vrednosti, v katerih je vsota enot 193.464. 


\section{Uporabljene spremenljivke}

Najpomembnejša dimenzija, ki nas v prispevku zanima, so besedilne spretnosti, merjene $\mathrm{z}$ desetimi spremenljivkami. Skupna besedilna spretnost je zajeta $\mathrm{v}$ eni razmernostni spremenljivki, neodvisne spremenljivke pa zajemajo: spol; slovenščino kot materni jezik (pri 93,3 \% mladostnikih); rojen v Sloveniji (takšnih je 95,7 \% mladih); izobrazbo matere/skrbnice; izobrazba očeta/skrbnika; število knjig, v gospodinjstvu; eno od vprašanj je merilo prostovoljsko delo $\mathrm{v}$ nepridobitnih organizacijah, ki smo ga tudi uporabili kot neodvisno spremenljivko; zdravje posameznika in udeležba $v$ formalnem izobraževanju v zadnjih dvanajstih mesecih (glej tabelo 32, ki predstavlja deleže in populacijske vrednosti).

Tabela 32: Frekvenčna porazdelitev neodvisnih spremenljivk na populaciji mladih, starih od 16 do 24 let

\begin{tabular}{|c|c|c|c|}
\hline Spremenljivka & Kategorije & $\mathrm{N}$ & $\%$ \\
\hline \multirow{2}{*}{ spol } & moški & 100.098 & 51,7 \\
\hline & ženski & 93.366 & 48,3 \\
\hline \multirow{2}{*}{ materni jezik } & da & 180.593 & 93,3 \\
\hline & ne & 12.872 & 6,7 \\
\hline \multirow{2}{*}{ rojen v Sloveniji } & da & 185.205 & 95,7 \\
\hline & ne & 8259 & 4,3 \\
\hline \multirow{3}{*}{ izobrazba matere } & ISCED $1,2,3$, kratek & 30.098 & 15,8 \\
\hline & ISCED 3 brez $3 \mathrm{C}_{4}$ & 107.399 & 56,5 \\
\hline & ISCED 5,6 & 52.711 & 27,7 \\
\hline \multirow{3}{*}{ izobrazba očeta } & ISCED $1,2,3$, kratek & 27.111 & 14,4 \\
\hline & ISCED 3 brez $3 \mathrm{C}_{4}$ & 115.823 & 61,5 \\
\hline & ISCED 56 & $45 \cdot 316$ & 24,1 \\
\hline \multirow{6}{*}{ število knjig doma } & $10 \mathrm{knjig}$ ali manj & 27.399 & 14,2 \\
\hline & 11-25 knjig & 38.255 & 19,8 \\
\hline & 26-100 knjig & 68.997 & 35,7 \\
\hline & 101-200 knjig & 29.185 & 15,1 \\
\hline & 201-500 knjig & 20.499 & 10,6 \\
\hline & več kot 500 knjig & 8813 & 4,6 \\
\hline
\end{tabular}




\begin{tabular}{|c|c|c|c|}
\hline Spremenljivka & Kategorije & $\mathrm{N}$ & $\%$ \\
\hline \multirow{5}{*}{$\begin{array}{l}\text { prostovoljsko delo v nepridobitnih } \\
\text { organizacijah }\end{array}$} & nikoli & 108.697 & 56,2 \\
\hline & manj kot enkrat na mesec & 39.781 & 20,6 \\
\hline & $\begin{array}{l}\text { manj kot enkrat na teden, a vsaj } \\
\text { enkrat na mesec }\end{array}$ & 24.609 & 12,7 \\
\hline & vsaj enkrat na teden, a ne vsak dan & 18.125 & 9,4 \\
\hline & vsak dan & 2253 & 1,2 \\
\hline \multirow{5}{*}{ zdravje } & odlično & 79.762 & 41,2 \\
\hline & zelo dobro & 67.984 & 35,1 \\
\hline & dobro & 38.167 & 19,7 \\
\hline & zadovoljivo & 6203 & 3,2 \\
\hline & slabo & 1349 & 0,7 \\
\hline \multirow{2}{*}{$\begin{array}{l}\text { v zadnjih dvanajstih mesecih je } \\
\text { bil udeležen v formalnem izobra- } \\
\text { ževanju }\end{array}$} & ni sodeloval & 27.265 & 14,1 \\
\hline & je sodeloval & 166.200 & 85,9 \\
\hline
\end{tabular}

Vir: OECD, 2016, lastni izračuni.

\section{Statistična analiza}

Vse statistične analize so bile izvedene na podvzorcu mladih, starih od 16 do 24 let $(\mathrm{n}=836)$, ki predstavljajo populacijo 193.464 mladih v Sloveniji. Podatki so bili obdelani z metodami univariatne analize (frekvenčne distribucije, povprečja, standardni odkloni), bivariatne in multivariatne analize. Povezanost vseh neodvisnih spremenljivk $\mathrm{z}$ besedilnimi spretnostmi mladih, ki je razmernostna spremenljivka, smo preverjali s t-testom za dva neodvisna vzorca v primeru, ko je imela naša neodvisna spremenljivka dve kategoriji in analizo variance ANOVA za vse neodvisne spremenljivke $\mathrm{z}$ več kot dvema kategorijama. Ugotavljanje, katera od izbranih neodvisnih spremenljivk ima največjo napovedno moč mladostnikove besedilne spretnosti, smo izpeljali z multiplo linearno regresijsko analizo.

\section{Rezultati}

S t-testom za dva neodvisna vzorca smo iskali dejavnike, ki vplivajo na besedilne spretnosti mladih. Razkril je, da vse zajete spremenljivke kažejo statistično značilne razlike $\mathrm{v}$ besedilnih spretnostih med dvema kategorijama spremenljivke (tabela 33); vsi t-testi imajo statistično značilnost manjšo od o,oo1. Ženske dosegajo višje besedilne spretnosti $(276,95)$ kot moški $(269,46)$; mlajši odrasli, katerih slovenščina je materni jezik, dosegajo višje besedilne spretnosti $(274,44)$ od mladih $\mathrm{z}$ drugim maternim jezikom 
(253,99); prav tako rojeni v Sloveniji $(273,87)$ za razliko od tistih, ki to niso $(255,25)$. Statistično značilne razlike so tudi $v$ ravneh besedilnih spretnosti med mladimi, ki so bili v zadnjih dvanajstih mesecih udeleženi v formalnem izobraževanju (277,77), in tistimi, ki niso bili udeleženi $(244,44)$.

Tabela 33: T-test za dva neodvisna vzorca (odvisna spremenljivka: besedilne spretnosti*)

\begin{tabular}{|c|c|c|c|c|c|c|}
\hline & & $\mathrm{N}$ & Povprečje & $\begin{array}{l}\text { Standar- } \\
\text { dni } \\
\text { odklon }\end{array}$ & $\mathrm{t}$ & $\mathrm{p}$ \\
\hline \multirow{2}{*}{ Spol } & moški & 100.098 & 269,46 & 39,79 & \multirow{2}{*}{$-45,092$} & \multirow{2}{*}{$\mathrm{p}<\mathrm{o}, \mathrm{oo} 1$} \\
\hline & ženski & 93.366 & 276,95 & 33,16 & & \\
\hline \multirow{2}{*}{$\begin{array}{l}\text { Materni jezik } \\
\text { slovenščina }\end{array}$} & $\mathrm{da}$ & 180.593 & 274,44 & 35,92 & \multirow{2}{*}{50,722} & \multirow{2}{*}{$\mathrm{p}<0,001$} \\
\hline & ne & 12.872 & 253,99 & 44,73 & & \\
\hline \multirow{2}{*}{ Rojen v Sloveniji } & $\mathrm{da}$ & 185.205 & 273,87 & 36,46 & \multirow[b]{2}{*}{39,275} & \multirow{2}{*}{$\mathrm{p}<0,001$} \\
\hline & ne & 8259 & 255,25 & 42,39 & & \\
\hline \multirow{2}{*}{$\begin{array}{l}\text { V zadnjih dva- } \\
\text { najstih mesecih je } \\
\text { bil udeležen v for- } \\
\text { malnem izobraže- } \\
\text { vanju }\end{array}$} & ni sodeloval & 27.265 & 244,44 & 38,342 & \multirow[b]{2}{*}{$-134,88$} & \multirow[b]{2}{*}{$\mathrm{p}<0,001$} \\
\hline & je sodeloval & 166.200 & 277,77 & 34,49 & & \\
\hline
\end{tabular}

* Besedilne spretnosti mladih dosegajo vrednosti od 116,64 do $357,73(\mathrm{P}=273,08 ; \mathrm{SO}=36,93)$. Vir: OECD, 2016, lastni izračuni.

V nadaljevanju smo merili statistično značilno razliko med različnimi kategorijami spremenljivk, ki imajo več kot dve kategoriji: izobrazba očeta/skrbnika in matere/skrbnice, zdravje posameznikov, število knjig $\mathrm{v}$ gospodinjstvu in sodelovanje $\mathrm{v}$ nepridobitnih organizacijah. Zaradi izločitve kategorij s premajhnim številom enot smo pri spremenljivki zdravje združili zadnji dve kategoriji v eno (zadovoljivo in slabo); pri spremenljivki prostovoljsko delo v nepridobitnih organizacijah smo združili kategoriji vsaj enkrat na teden in vsak dan v eno; pri spremenljivki število knjig $\mathrm{v}$ gospodinjstvu pa smo združili kategoriji 201-50o knjig in več kot 500 knjig v eno kategorijo, več kot 200 knjig. Test ANOVA najprej izračuna, ali je med vsaj eno dvojico kategorij v spremenljivki statistično značilna razlika (F-test), podrobneje pa post-hoc test izračuna statistično značilne razlike med vsako dvojico kategorij te spremenljivke. Te izpise navajamo sumarno v zadnjem stolpcu tabele 34 .

Analiza variance pokaže statistično značilno povezanost vseh petih spremenljivk $\mathrm{z}$ besedilnimi spretnostmi (statistična značilnost statistike $\mathrm{F}$ je v vseh primerih manjša od o,oo1). Bonferroni post-hoc test pokaže stati- 
stično značilne razlike $\mathrm{v}$ besedilnih spretnostih vseh dvojic kategorij spremenljivke izobrazba matere/skrbnice: nižja $(258,1)$, srednja $(269,7)$ in višja (290). Kažejo se tudi statistično značilne razlike $\mathrm{v}$ besedilnih spretnostih med vsemi dvojicami spremenljivke izobrazba očeta/skrbnika: nižja $(256,4)$, srednja $(270,4)$ in višja $(291,5)$.

Post-hoc test pokaže statistično značilne razlike med vsemi dvojicami kategorij spremenljivke zdravje: odlično $(271,9)$, zelo dobro $(277,9)$, dobro $(270,4)$ zadovoljivo ali slabo $(254,8)$. Statistično značilne razlike so tudi med večino dvojic spremenljivke prostovoljsko delo v nevladnih organizacijah: nikoli $(271,4)$, manj kot enkrat na mesec $(273,1)$, manj kot enkrat na teden, a vsaj enkrat na mesec $(271,9)$, vsaj enkrat na mesec ali vsak dan $(283,4)$. Pri spremenljivki število knjig v gospodinjstvu so statistično značilne razlike med vsemi dvojicami kategorij te spremenljivke: do 10 knjig $(252,4), 11-$ 25 knjig (260,2), 26-100 knjig (273,6), 101-200 knjig 285,6), nad 200 knjig $(295,7)$.

Tabela 34: Analiza variance (odvisna spremenljivka: besedilne spretnosti)

\begin{tabular}{|c|c|c|c|}
\hline & $\mathrm{F}$ & $\mathrm{p}$ & $\begin{array}{l}\text { Statistične razlike (post-hoc test) } \\
\text { se kažejo }\end{array}$ \\
\hline Izobrazba matere/skrbnice & 9322,991 & $\begin{array}{c}\mathrm{p}< \\
0,001\end{array}$ & med vsemi dvojicami treh kategorij \\
\hline Izobrazba očeta/skrbnika & 9610,569 & $\begin{array}{c}\mathrm{p}< \\
\mathrm{o}, \mathrm{001}\end{array}$ & med vsemi dvojicami treh kategorij \\
\hline Zdravje & 1123,492 & $\begin{array}{c}\mathrm{p}< \\
\mathrm{o}, 001\end{array}$ & med vsemi dvojicami štirih kategorij \\
\hline $\begin{array}{l}\text { Prostovoljsko delo v nevladnih or- } \\
\text { ganizacijah }\end{array}$ & 626.130 & $\begin{array}{c}\mathrm{p}< \\
0,001\end{array}$ & $\begin{array}{l}\text { med vsemi dvojicami kategorij razen } \\
\text { med »nikoli« in »manj kot enkrat na } \\
\text { teden, a vsaj enkrat na mesec« }\end{array}$ \\
\hline Število knjig v gospodinjstvu & 8021,110 & $\begin{array}{c}\mathrm{p}< \\
0,001\end{array}$ & med vsemi dvojicami petih kategorij \\
\hline
\end{tabular}

Vir: OECD, 2016, lastni izračuni.

V nadaljevanju smo želeli ugotoviti, katera od izbranih neodvisnih spremenljivk ima največjo napovedno moč besedilne spretnosti mladostnika. Uporabili smo multiplo linearno regresijsko analizo. V regresijski model smo uvrstili neodvisne spremenljivke: zdravje, izobrazba matere/skrbnice, izobrazba očeta/skrbnika, število knjig v gospodinjstvu, sodelovanje $\mathrm{v}$ nepridobitnih organizacijah in $\mathrm{spol}^{2}$. 
Regresijski model z uvrščenimi devetimi neodvisnimi spremenljivkami pojasnjuje 22,7\% variance odvisne spremenljivke besedilne spretnosti in je stabilen. Vrednost statistike F je 6049,47; p < o,oo1. Tabela 35 kaže na to, da osem neodvisnih spremenljivk od devetih vpliva na besedilne spretnosti. Edina spremenljivka, ki nanjo ne vpliva, je prostovoljsko delo $\mathrm{v}$ nevladnih organizacijah $\mathrm{v}$ zadnjih dvanajstih mesecih $(\mathrm{t}=-0,041 ; \mathrm{p}=0,967)$. Med drugimi spremenljivkami, ki vplivajo na besedilne spretnosti, nam standardizirani koeficient beta pove, katera od teh spremenljivk vpliva najmočneje in katera manj močno. Opazimo lahko, da najmočneje vplivata spremenljivki število knjig $v$ gospodinjstvu $(\beta=0,253)$, ta pomeni večjo besedilno pismenost mladostnika, ki živi obdan z večjim številom knjig, in pa udeležba $\mathrm{v}$ formalnem izobraževanju $(\beta=0,225)$, ki se kaže $\mathrm{v}$ višji besedilni pismenosti kot pri mladostnikih, ki niso udeleženi v formalnem izobraževanju. Takoj za njo sledijo izobrazba očeta/skrbnika $(\beta=0,117)$, materni jezik slovenščina $(\beta=0,061)$ in izobrazba matere/skrbnice $(\beta=0,046)$. Višja izobrazba staršev ali skrbnikov je povezana $z$ višjimi besedilnimi spretnostmi mladostnika, prav tako slovenščina kot materni jezik.

Tabela 35: Koeficienti regresijske analize (odvisna spremenljivka besedilne spretnosti)

\begin{tabular}{|c|c|c|c|c|c|}
\hline & \multicolumn{2}{|c|}{$\begin{array}{l}\text { Nestandardizirani } \\
\text { koeficienti }\end{array}$} & \multirow{2}{*}{$\begin{array}{c}\begin{array}{c}\text { Standardi- } \\
\text { zirani koe- } \\
\text { ficienti }\end{array} \\
\text { beta }\end{array}$} & \multirow[t]{2}{*}{$\mathrm{t}$} & \multirow[t]{2}{*}{$\mathrm{p}$} \\
\hline & B & std. napaka & & & \\
\hline konstanta & 203,658 & 0,514 & & 396,235 & $\mathrm{p}<\mathrm{o,001}$ \\
\hline moški spol & $-1,673$ & 0,156 & $-0,023$ & $-10,728$ & $\mathrm{p}<0,001$ \\
\hline izobrazba matere/skrbnice & 2,645 & 0,147 & 0,046 & 18,026 & $\mathrm{p}<0,001$ \\
\hline izobrazba očeta/skrbnika & 7,061 & 0,149 & 0,117 & 47,495 & $\mathrm{p}<0,001$ \\
\hline število knjig v gospodinjstvu & 7,100 & 0,066 & 0,253 & 108,043 & $\mathrm{p}<0,001$ \\
\hline $\begin{array}{l}\text { prostovoljsko delo v nevladnih } \\
\text { organizacijah }\end{array}$ & $-20,003$ & 0,072 & 0,000 & $-0,041$ & $\mathrm{p}=0,967$ \\
\hline zdravstveno stanje & $-0,751$ & 0,088 & $-0,018$ & $-8,571$ & $\mathrm{p}<0,001$ \\
\hline materni jezik & 9,107 & 0,378 & 0,061 & 24,106 & $\mathrm{p}<\mathrm{o,001}$ \\
\hline rojen v državi & 1,164 & 0,458 & 0,006 & 2,541 & $\mathrm{p}=0,011$ \\
\hline $\begin{array}{l}\text { udeležen v formalnem izobra- } \\
\text { ževanju v zadnjih dvanajstih } \\
\text { mesecih }\end{array}$ & 23,942 & 0,229 & 0,225 & 104,482 & $\mathrm{p}<0,001$ \\
\hline
\end{tabular}

Vir: OECD, 2016, lastni izračuni. 


\section{Razprava}

Raven formalne izobrazbe ima temeljno vlogo pri pojasnjevanju besedilnih spretnosti mladih. Višja formalna izobrazba je povezana $\mathrm{z}$ višjimi dosežki. Možina (2017) je na podlagi podatkov raziskave PIAAC ugotovila, da so velike razlike v spretnostih mladih, ki se izobražujejo, in spretnostih njihovih vrstnikov, ki tega ne počnejo.

Pri pojasnjevanju spretnosti mladih, kjer je izrazita povezanost med ravnijo formalne izobrazbe in dosežki, je treba upoštevati širše ozadje. Slovenija je država, ki se sooča $z$ največjim upadom priložnosti in delovnih mest za nizkokvalificirane, manj izobražene in prebivalce $\mathrm{z}$ nizkimi spretnostmi. Raven spretnosti, ki jo delodajalci praviloma povezujejo z ravnjo dokončane formalne izobrazbe, je pogostokrat poglavitni kriterij odločanja pri zaposlovanju. Med različnimi spretnostmi mladih so za njihovo zaposljivost najpomembnejše besedilne spretnosti. A hkrati besedilne spretnosti krepijo tudi državljanske spretnosti. Posamezniki z višjimi besedilnimi spretnostmi se bolj zanimajo za politiko, večji odstotek se jih udeleži volitev, so bolj obveščeni ter bolj zaupajo politikom in političnim institucijam. Izobraževanje pomeni dandanes izhod iz socialne izključenosti, saj so stopnje spretnosti, ki se zahtevajo $\mathrm{v}$ današnjem času, vedno višje (Vrečer, 2011).

Število knjig je pomemben kazalnik razvitosti besedilnih spretnosti in navad mladih v Sloveniji. Analiza je potrdila, da med mladimi velja teorija "aktivne rabe spretnosti«. Raven spretnosti in branje knjig se med seboj spodbujata. Redkejša raba bralnih praks v vsakdanjem življenju negativno vpliva na raven spretnosti. Širša analiza je sicer pokazala, da je v populaciji odraslih izrazita korelacija med številom knjig in besedilnimi spretnostmi (Javrh, 2020). To pomeni, da odrasli, ki imajo v gospodinjstvu več knjig, lažje povezujejo, interpretirajo ali sintetizirajo informacije ter pri branju globlje sklepajo.

V modelu ima izobrazba staršev/skrbnikov pomembno vlogo pri pojasnjevanju besedilnih spretnosti mladih. Pri starostni kategoriji od 16. do 24 . leta je izobrazba očeta/skrbnika pomembnejši dejavnik, ki napoveduje raven spretnosti mladih. Sledi izobrazba matere/skrbnice. Dosežki mladih, katerih očetje/skrbniki in matere/skrbnice dosegajo nizke formalne izkaze, so relativno nizki. Velja tudi obrnjeno. Pri bolj izobraženih starših/skrbnikih so besedilne spretnosti potomcev mnogo višje.

Število knjig $v$ gospodinjstvu in izobrazba staršev/skrbnikov potrjujeta pomembno vlogo družine pri razvoju spretnosti (angl. long arm of the family). Bolj izobraženi starši ustvarjajo spodbudnejše družinsko okolje za 
pridobivanje spretnosti (med temi je tudi zagotovitev večjega števila knjig) ter prenašajo vrednote, navade in prepričanja, ki visoko vrednotijo znanje in spretnosti. (Boudard in Rubenson, 2004).

Primerjava po spolu v našem modelu potrjuje, da je razlika statistično značilna, a šibka med moškimi in ženskami v obdobju med 16. in 24. letom starosti. Ženske v tem obdobju imajo višje besedilne spretnosti kot moški.

Materni jezik je v regresijskem modelu pomembna spremenljivka, ki napoveduje razvitost besedilne spretnosti prebivalcev od 16. do 24. leta starosti. Hkrati je razvitost teh pomemben napovedovalec razvoja drugih spretnosti (matematičnih, digitalnih, spretnosti reševanja problemov v tehnološko razvitih okoljih itn.). Povezanost med maternim jezikom in ravnjo besedilnih spretnosti ni značilna le za populacijo mladih in tudi ne le za Slovenijo. Raziskava PIAAC je pokazala, da so povezave med tema dvema spremenljivkama izrazite predvsem na Češkem in v Veliki Britaniji (Skills Matter, 2016). Materni jezik je imanentna identiteta vsakega posameznika. Bauman (2018) deli najbolj izključene na dve skupini, ki ju opredeli v odnosu do identitete. Po njegovem ima večina ljudi večjo ali manjšo svobodo izbire lastne identitete; večina, a ne vsi - nekateri te svobode nimajo. Taki so na primer migranti: »Odrivamo jih v siva območja za nikogaršnje ljudi, kjer se ne morejo socializirati«, in zato po mnenju Baumana (2018) ne morejo razviti svoje identitete.

Raziskava opozarja, da so mladi, ki živijo zunaj meja svoje države, izpostavljeni temu, da prej končajo redno izobraževanje - simptomatično so njihove spretnosti na vseh treh področjih nižje. Ta status negativno vpliva na mentalno in emocionalno zdravje mladih ter na njihovo družbeno vključenost. Ta izid je vsekakor znamenje, ki opozarja, da je treba posebej poskrbeti in motivirati mlade, ki so glede spretnosti prikrajšani, da $\mathrm{z}$ ustreznimi strategijami ta manko zmanjšajo ali tudi odpravijo.

Spremenljivka zdravje se je pokazala kot statistično pomembna pri pojasnjevanju spretnosti populacije odraslih do 65. leta starosti, zato je bila uvrščena v model. Pri populaciji mladih zdravstveno stanje ni zelo pomemben dejavnik za pojasnitev ravni njihovih spretnosti. Zaznali smo šibko zvezo 3 med obema spremenljivkama, ki pomeni, da imajo mladi, ki bolje ocenjujejo svoje zdravje, višje besedilne spretnosti.

Model tudi ni pokazal povezanosti med udeležbo v prostovoljskih združenjih in ravnjo spretnosti populacije od 16. do 24. leta starosti.

3 Zaradi obrnjene lestvice ( 1 pomeni odlično in 5 slabo) je koeficient beta negativen, a pomeni pozitivno povezanost. 


\section{Sklep}

Temeljni dokumenti in smernice Evropske unije, Unesca in OECD poudarjajo vlogo spretnosti prebivalstva kot dejavnik družbenega, gospodarskega in individualnega razvoja. Raziskava PIAAC je razkrila, da je Slovenija med evropskimi državami, ki so v njej sodelovale, pod povprečjem Evropske unije in OECD. V Sloveniji se kažejo tudi velike razlike $v$ besedilni spretnosti glede na starost, doseženo izobrazbo, značilnosti dela, način preživljanja prostega časa itn. (Skills Matter, 2016).

Spretnosti mladih, ki so najvitalnejši del družbe, so izjemnega pomena. Ule (2011) je napovedala večje zanimanje za spretnosti mladih, ker postajajo vse pomembnejši dejavnik v družbi znanja, hkrati pa je obdobje mladosti prehodno obdobje. Prehodi so po njenem mnenju temeljnega pomena. Posamezniki, ki imajo v prehodnem obdobju dovolj podpore, lahko izkoristijo različne priložnosti za pridobivanje znanja in spretnosti, drugi, ki teh priložnosti nimajo, postajajo ranljivejši.

V prispevku so predstavljene besedilne spretnosti mladih oziroma populacije od 16. do 24. starosti. To je čas biološke zrelosti in prevzemanja vlog odraslih.

Cilj prispevka je bil ugotoviti stanje besedilnih spretnosti populacije od 16. do 24. leta starosti in proučiti dejavnike, ki na to stanje in gibanja vplivajo bolj ali manj ugodno.

Besedilne spretnosti odraslih (od 16 do 65 let) so v Sloveniji nižje od povprečja OECD in Evropske unije, a te razlike so najmanjše v populaciji od 16. do 24. leta starosti.

Primerjalna analiza je pokazala, da ima skupina mladih v Sloveniji bolj razvite besedilne spretnosti kot druge starostne kategorije, zajete v raziskavo. Proučevanje dosežkov kaže, da med mladimi prevladujejo dosežki na tretji ravni besedilnih spretnosti, ki so sicer pogoj za delovanje v družbi, temelječi na znanju. Kljub razmeroma dobrim dosežkom mladih - v primerjavi z višjimi starostnimi kategorijami - ne smemo spregledati, da več kot $50 \%$ populacije od 16. do 24. leta starosti nima ustreznih spretnosti za ravnanje s sodobnimi informacijami, ki jih vsebujejo različne vrste besedil, obrazci in slikovni prikazi, in za uporabo teh v novih okoliščinah.

Regresijski model je potrdil, da so spretnosti mladih celosten fenomen. Dejavniki, ki najbolj pojasnjujejo raven njihovih spretnosti, so: dokončana formalna izobrazba, število knjig $\mathrm{v}$ gospodinjstvu, izobrazba staršev/skrbnikov in jezik, ki so se ga posamezniki naučili ob rojstvu. Nekateri dejavniki, na primer splošno zdravje in sodelovanje v prostovoljskih zdru- 
ženjih, ki napovedujejo besedilne spretnosti celotne populacije odraslih, pri mladih nimajo take napovedovalne vrednosti. Zaradi izrazitega vpliva proučevanih dejavnikov nastajajo v Sloveniji večje razlike že v mladosti. Poglabljanje polarizacije med mladimi ni v skladu s sodobnimi družbenimi gibanji in razvojem. Večajo se razlike med mladimi, ki študirajo, so samozavestni pri iskanju zaposlitve in vključevanju v družbeno, državljansko in kulturno življenje, in tistimi, ki imajo malo upanja, da bodo vodili izpolnjujoče življenje in so izpostavljeni tveganju izključenosti in marginalizacije. Pri tem se postavlja vprašanje, kako lahko zunaj sistema izobraževanja in predvsem rednega šolanja kompenziramo primanjkljaje v spretnostih in kako angažirati mlade, ki so manj motivirani in ne uporabljajo spretnosti v vsakdanjem življenju in delu?

Svet ministrov Evropske unije je sprejel številne dokumente in ponudil iztočnice sodelovanja na vseh področjih, ki vplivajo na kakovost bivanja mladih. Ti dokumenti poudarjajo predvsem oblikovanje in uresničevanje ukrepov za preprečevanje zgodnjega osipa in daljše neaktivnosti. A cilj evropske politike ni le to, da čim več mladih pritegnejo k izobraževalni dejavnosti, temveč omogočiti učenje tudi zunaj formalnega sistema izobraževanja, odpreti prostor za učinkovitejši trg dela, doseči večjo socialno in ekonomsko pravičnost.

\section{Literatura}

Bauman, Zygmunt, Thomas Leoncini, Bojan Žalec in Vasja Bratina. Tekoča Generacija: Spremembe v Tretjem Tisočletju. Ljubljana: Družina, 2018.

Berzin, Cosner, Stephanie. »Vulnerability in the Transiotion to Adulthood: Defining Risk Based on Youth Profiles«. Children and Youth Services Review 32, št. 4 (2010): 487-495.

Boudard, Emmanuel in Kjell Rubenson. »Revising Major Determinants of Participation in Adult Education with a Direct Measure of Literacy Skills«. International Journal of Educational Research 39, št. 3 (2003): 265-281.

Drucker, F. Peter. Managing in a Time of Greater Change. New York: Truman Talley Books, Dutton, 1995.

»Evropa 2020: Strategija za pametno, trajnostno in vključujočo rast«. Europe 2020. European Commission. January 7. 2015. http://ec.europa.eu/ eu2020/pdf/1_SL_ACT_part1_v1.pdf.

Javrh, Petra. »Delovno aktivni prebivalci z najnižjimi spretnostmi - specifične značilnosti.« V Delovno aktivni prebivalci z nižjimi spretnostmi (ur. Petra Javrh). Ljubljana: Andragoški center Slovenije, 2020. 
Krajnc, Ana. »Gospodarska kriza, znanje in izobraževanje«. Gospodarstvo v recesiji in izobraževanje odraslih. Ljubljana: Andragoški center Slovenije, 2011.

Literacy in the Information Age - Final Report of the International Adult Literacy Survey. Organisation for Economic Co-operation and Development. Paris: Statistics Canada, 2000.

Mirčeva, Jasmina in Ester Možina. Kompetence odraslih od 16. do 64. leta: longitudinalni in mednarodni vidiki. Ljubljana: Andragoški center Slovenije, 2017.

Mladi v akciji. Vodnik po programu. October 10, 2020, https://ec.europa.eu/assets/eac/youth/tools/documents/guide13_si.pdf.

Muršak, Janko. Terminološki vidiki projekta PIAAC. Preliminarno poročilo. Tematske študije. Interno gradivo. Ljubljana: Andragoški center Slovenije, 2016.

Muršak, Janko in Marko Radovan. Razvoj spretnosti in kompetenc, značilnosti delovnega okolja in vključenost v neformalno izobraževanje. Preliminarno poročilo: Tematske študije. Interno gradivo. Ljubljana: Andragoški center Slovenije, 2015.

Mužica, Rozana. Uvod: Lokalna mladinska politika. Ljubljana: Zveza ŠKIS, Ajdovščina: Mladinski svet, 2012.

OECD Skills Surveys. Survey of Adult Skills. PIAAC_SLO 2016 Ljubljana: Andragoški center Slovenije (interna baza podatkov).

Ragin, Charles. Družboslovno raziskovanje - enotnost in raznolikost metode. Ljubljana: Fakulteta za družbene vede, 2007.

Statistical Office of the European Communities. 1990. EUROSTAT: Regional statistics.: Reference guide. Luxembourg: Eurostat.

Skills Matter: Further Results from the Survey of Adult Skills. Paris: OECD Publications, 2016.

Ule, Mirjana. »Prehodi v odraslost in spretnosti odraslih«. V Spretnosti odraslih (ur. Petra Javrh). Ljubljana: Andragoški center Slovenije, 2018.

Ule, Mirjana in Marija Zidar. Life Course, Educational Trajectories and Social Integration of Young People in Slovenia. Teorija in praksa 48., 5/2011.

Vrečer, Natalija. Posledice izključevanja iz izobraževanja za zaposlovanje, zdravje, stanovanjsko področje in politično participacijo. Obrazi pismenosti. Ljubljana: Andragoški center Slovenije, 2011.

Zakon o mladinskem interesu v javnem sektorju. July 20, 2017, http://www. pisrs.si/Pis.web/pregledPredpisa?id=ZAKO5834.

Zakon o mladinskih svetih (2000). November 2, 2020, ttp://www.pisrs.si/Pis. web/pregledPredpisa?id=ZAKO2614. 